Research Article

\title{
Sustainable shotcrete production with waste glass aggregates
}

\author{
Mehdi Serati $^{1}{ }^{1} \cdot$ Niki Jakson $^{2} \cdot$ Harry Asche $^{1} \cdot$ Sai Basireddy $^{1} \cdot$ Gautam Malgotra $^{1}$
}

Received: 8 November 2021 / Accepted: 24 January 2022

Published online: 19 February 2022

(c) The Author(s) 2022 OPEN

\section{Abstract}

This study employs statistical and experimental procedures to assess the applicability of crushed waste glass to replace natural sand in shotcrete production for use in tunneling, mining and excavation industries as a support system. Mechanical strength under different uniaxial and biaxial load combinations, fracture properties, and ultra-high-speed photography of the crack growth mode in the newly developed shotcrete mixes were studied and compared against the control mix at $0 \%$ waste glass inclusion. Results suggest that shotcrete mixes containing synthetic glass aggregates exhibit similar or higher strength properties (compared with conventional shotcrete with natural aggregates) at early and late ages in both fresh and hardened shotcrete samples. Under biaxial stress conditions, in particular, the new glass shotcrete designs demonstrate a higher load-bearing capacity of up to $35 \%$ increase. Compared to conventional shotcrete, replacing sand with recycled glass aggregates further exhibited the need for less water and binder consumption owing to the glass water-reducing effect. This in return could leave more water available for improved workability in the mixture hence producing a more cost-effective and eco-friendly shotcrete product. From the results, no impairment of performance was recorded by substituting sand with crushed waste glass even at a high substitution percentage of up to $100 \%$; suggesting high improvement potential of crushed waste glass re-use in the shotcrete industry.

\section{Article highlights}

- This study investigates sand replacement with glass aggregates in shotcrete productionfor use in excavation industry.
- Tested shotcrete mixes containing glass aggregates exhibited a similar or higher strengthproperties at both early and late ages.

- Results suggest that waste glass reuse as synthetic aggregates can reduce water andcement consumption to generate a low-cost and eco-friendly shotcrete.

Keywords Sustainability $\cdot$ Shotcrete $\cdot$ Sand depletion $\cdot$ Crushed waste glass $\cdot$ Mechanical properties

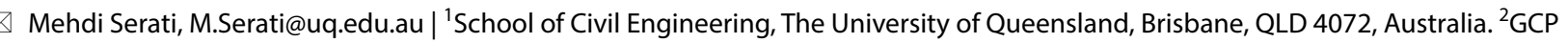
Applied Technologies, Sydney, NSW 2565, Australia.

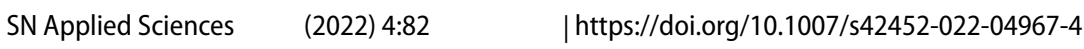




\section{Background and motivations}

According to the International Tunnelling Association, the global demand for underground construction will boom in the coming years, with around AUD 42 billion of investment in the tunnelling sector in Australia alone. This trend, in fact, can be seen already with 9 out of the 12 current state and federal government infrastructure projects related to tunnelling in Australia [1]. With such an increased demand for tunnelling, shotcrete has also received increasing attention for ground support in tunnels and mines. In 2018, for instance, there was 800,000 $\mathrm{m}^{3}$ of shotcrete used in Australia of which $500,000 \mathrm{~m}^{3}$ was used in underground construction and $300,000 \mathrm{~m}^{3}$ in civil basements, swimming pools and embankments [2]. Table 1 provides a list of Australia's current and future major tunnelling projects with significant portions of shotcrete supported tunnelling. Shotcrete (aka Sprayed Concrete) is fundamentally concrete that is pneumatically projected onto the target surface from a nozzle at a high (typically $20-30 \mathrm{~m} / \mathrm{s}$ ) velocity to generate a dense homogeneous mass [2-4]. Given its unique placement method, shotcrete is also known as pneumatic concrete, guncrete, gunite when used as dry-mix, and fibre-crete if used in mining operations. The Australian and American concrete industries typically refer to shotcrete using the above terms where each guideline is named accordingly, i.e. ACI 506.4R-94 Guide for the Evaluation of Shotcrete [5] and the Recommended Practice - Shotcreting in Australia [2]. In Europe, the term sprayed concrete is used in the specifications produced by EFNARC [6] and also the British standard BS EN 14487-1 and $2[7,8]$.

The invention of shotcrete can be attributed to Carl Ethan Akeley, a famous hunter and professor, who trialled a dry mixed mortar on skeletal matrices for taxidermy purposes in 1907 [9]. He further refined his crude original machine by adding a supplementary compression chamber and geared feed-wheels, and in 1911 patented his improved system that still resembles the drymix process used today $[10,11]$. Dry-mix refers to the method by which the cement and the aggregates are blended and then placed into a special-purpose machine where the materials are then pneumatically conveyed to the nozzle where water is introduced to wet the mixture before it is pneumatically projected. The mix can also contain fibres and admixtures $[2,9,10]$. In contrast, in the wet-mix process, the cement, aggregate and water are batched and combined and the mix is then delivered to the site where the concrete is pumped to the nozzle. At the nozzle, compressed air is introduced and the mix is pneumatically projected-admixtures are normally used and may include fibres $[2,9,10]$. Where an accelerator is added at the nozzle, the mix is often referred to as nozzle accelerated shotcrete.

But, unlike conventional concrete (in which compaction is achieved by vibration to flush out air through a completely separate process after placement), shotcrete placement and compaction is done simultaneously as soon as it impacts the surface. Shotcrete also requires higher pumpability and workability properties than concrete as the site where shotcrete is needed and the location where shotcrete mixing is performed are often far away. Shotcrete needs to have a certain level of instance (i.e. early-age) strength within only a few hours after it is discharged, while in concrete design the 28-day strength is mainly the critical parameter. In addition, shotcrete requires little or no formwork, hence is highly preferred over concrete where (1) formwork cannot be placed, (2) access to the work is difficult, (3) normal casting techniques cannot be used, (4) a thin and/or various concrete thickness profile is needed, or (5) in situations where customisation in shape, depth and style is required. The main uses for shotcrete are varied in today's construction industry, but can be

Table 1 Infrastructure projects in Australia with significant shotcrete lined tunnelling

\begin{tabular}{|c|c|c|c|}
\hline Name of Project & Location & Status & Comments \\
\hline WestConnex 3A & Sydney & Under construction & $\begin{array}{l}\text { Approx. } 15 \mathrm{~km} \text { of shotcrete-supported 3-lane road tunnels, ramps, } \\
\text { Y-junctions }\end{array}$ \\
\hline WestConnex 3B & Sydney & Under construction & Approx. $10 \mathrm{~km}$ of shotcrete-supported ramps and Y-junctions \\
\hline M6 & Sydney & In procurement process & Approx. $8 \mathrm{~km}$ of shotcrete-supported 3-lane road tunnels and ramps \\
\hline $\begin{array}{l}\text { Western Harbour Cross- } \\
\text { ing and Beaches Link }\end{array}$ & Sydney & Future project & $\begin{array}{l}\text { Approx. } 30 \mathrm{~km} \text { of shotcrete-supported 3-lane road tunnels, ramps, } \\
\text { Y-junctions }\end{array}$ \\
\hline Sydney Metro West & Sydney & In procurement process & Shotcreted caverns for stations and crossovers \\
\hline Coffs Harbour Bypass & Coffs Harbour & Future project & Approx. $2 \mathrm{~km}$ shotcrete-supported tunnels \\
\hline Melbourne Metro & Melbourne & Under construction & Shotcreted caverns for stations and crossovers \\
\hline Cross River Rail & Brisbane & Under construction & Shotcreted caverns for stations and crossovers \\
\hline Inland Rail & Brisbane & In procurement process & Approx. $2 \mathrm{~km}$ shotcrete-supported tunnels \\
\hline
\end{tabular}


summarised in the key categories of (1) support system in tunnels and underground excavations, (2) open pit mines, slopes and rock surface exposures against weathering and erosion, (3) fire protection of steelwork, (4) refractory linings, (5) concrete rehabilitation and repairs when major full-thickness repairs are uneconomical, and (6) rock and soil stabilisation.

For tunnel support applications, in particular, shotcrete is used in two slightly different ways. Where the ground is softer or where rockbolts are ineffective in reinforcing the ground, shotcrete is used in an arching action to assist the natural arching of the ground. In this type of ground support, the compressive stiffness and strength of the shotcrete is critical $[2,9,12]$. Where the ground can be reinforced by rockbolts, the shotcrete becomes a support for loose blocks between the rockbolts. Here, bending capacity becomes an important property in shotcrete design. Where bending strength is important, shotcrete can be reinforced conventionally by bars or mesh. However, the placing of bars and mesh overhead is undesirable in many ways, with issues of time, cost and safety. In Australia, the use of steel fibre reinforcement in lieu of mesh is often preferred. In deeper tunnels, the tendency for shotcrete to shrink and creep to relieve excessive ground deformations is a very useful property. However, in shallow tunnels where limiting deformations is important to avoid damage to surface facilities, shotcrete is reinforced with steel to reduce movement. Therefore, the important properties for shotcrete in tunnelling design include compressive strength, bending strength (which is related to tensile strength) and shrinkage. Moreover, since shotcrete is installed at the face and becomes loaded with face advance almost immediately, not just the hardened properties are important, but also the time-dependency of these properties.

To reduce rebound, shotcrete mixes usually use smaller aggregate. Additionally, to coat the surface, shotcrete mixes use an increased binder content compared to conventional concrete to improve the stickability and density. For these two reasons, shotcrete mixes tend to use a higher proportion of sand. In recent years, shotcrete supply has therefore suffered from a significant rise in the overall cost mainly due to steep hikes in the price of sand. This can be attributed to the widespread use of sand in today's blended aggregate industries (concrete, shotcrete, pavement, etc.) that has made sand the second-most consumed resource on earth (after freshwater) and the most important solid substance on the planet $[13,14]$. It is expected that sand will become the commodity of the 21 st century, like oil in the 20th century. According to the latest statistics, a staggering fifty billion tonnes of natural sand and aggregates is being consumed all over the world each year, which is equivalent to almost $18 \mathrm{~kg}$ per person living on earth per day (or twice the amount of sand produced by every river in the world) [15]. Amongst many applications, the construction industry requires the highest volume of (a steady) sand supply. It is true to say that about $75 \%$ of construction material is concrete of which two-thirds is sand. This has made sand mining a highlyprofitable 70 billion dollar industry, but at the expense of beaches losing their sand. Such unsustainable exhaustion of sand and natural aggregates has damaged aquatic habitats, caused beach erosion, made coastal communities vulnerable to floods, and has impacted biodiversity on land $[15,16]$. For example, up to $90 \%$ of the world's beaches have shrunk by $40 \mathrm{~m}$ on average over the last 10 years only due to beach sand extraction. Recycling local wastes to replace the rapidly reducing natural and quarried sand is therefore becoming of urgent interest in Australia and worldwide.

Among multiple types of waste, glass is a perfect costeffective candidate to replace sand, as glass (1) is theoretically $100 \%$ re-usable and can be infinitely recycled with no loss in performance or any reduction in quality, (2) is nonmiscible, non-flammable, inert, non-biodegradable, and does not degrade, $(3)$ is mainly composed of silica $\left(\mathrm{SiO}_{2}\right)$ which is a key mineral found in natural sand, and above all (4) has similar chemical compositions to that of natural sand [17]. There is an ever-increasing amount of waste glass generated worldwide that is currently sent to landfills while it has a high potential for re-use. Statistics show that waste glass accounted for $5 \%$ of all waste produced in the world globally in 2016, more than wood, rubber and leather waste combined $[18,19]$. In Australia alone, annual consumption of glass is 1.36 million tonnes, with Queensland producing nearly 350,000 tonnes-second only to the state of New South Wales [20]. The same concerns are heard across Europe, Asia, and the US. In addition, China's waste import restrictions (i.e., National Sword and Blue Sky policies), and the imminent implementation of waste export bans, place Australia's and many other countries' waste and resource recovery sectors under tremendous pressure. Australia's states and territories have also recently agreed to ban the export of their waste glass by 2024, meaning that the states must find ways to deal with their glass waste disposal that would usually ship overseas. Due to the non-biodegradable nature of glass, it is one of the longest-lasting man-made materials. For example, a glass bottle needs to stay in landfills for up to one million years before it is fully decomposed. Traditional landfilling and stockpiling of waste glass are therefore not environment-friendly solutions, and thus the re-use of waste glass to replace sand has become an important research topic worldwide.

Over the past decades, recycling crushed waste glass (CWG or cullet) has grown significantly in a range of 
applications including concrete production, tile and brick manufacturing, road pavement construction, water filtration, paint coatings and sealants, soil performance improvement, pipe bedding, sandblasting, glass wool insulation, and even plastics and paper production [15, 21-25]. But, large-volume CWG reuse has remained pitifully low in geotechnical domains and yet remains relatively under-investigated. This could be due to:

- access to yet cheaper (although not sustainable) natural aggregates in some places around the world;

- unrepresentative testing requirements for CWG reuse in geotechnical applications;

- lack of community-accepted and market-ready guidelines for the application of CWG in geotechnical fields;

- the perceived inferior quality of CWG as a reliable sand replacement;

- the hydrodynamical (HM), chemical (C), thermal $(\mathrm{T})$ and particularly coupled HTCM engineering properties of CWG from granular (at individual particles) to macro levels (in-placed two/three-phase characteristics when placed within geo-structures) not yet being fully understood. While the short-term behaviour of a CWG placed material structure can be studied in the laboratory or by field measurements, long-term behaviour is largely under-studied;

- while it is known that particle shape, size and gradation of CWG affect its physical performance quite substantially, there is limited engineering (and scientific) knowledge of how these particle descriptors combined could trigger thermo-hydro-chemo-mechanical coupling effects in waste glass geo-structures;

- the perception that raw CWG and CWG-embedded products could have issues with consistency, hence the lack of confidence in and the perceived risk associated with CWG-embedded products;

- lack of certification of CWG-embedded products;

- lack of experience in geotechnical applications for CWG re-use and industry's strong preference to work with known materials which have proved their consistency and quality over the years;

- issues related to recycling waste glass in some geotechnical applications that may require colour sorting (mainly into clear, green and amber), as well as extraction of impurities, metal and contaminants leading to high costs of transportation and capital intensive processes which in return prohibit large-scale waste glass utilisation;

- the fact that the adoption of non-virgin materials through a circular economy is a political goal in many countries that requires government intervention to stimulate action; and
- the fact that many current industries, including the construction industry, are not yet fully prepared to embrace changes towards a circular economy. Changing the status quo will require a strong push from government and regulators through, for example, stream recycling at the kerbside, bottle bills that encourage consumers to bring back empties at high rates, introducing higher taxes for glass landfilling, and incentives to create glass recycling centres that can sort, clean, and process the material with better precision and cleanliness.

One of the geotechnical-related areas in which the utilisation of CWG yet remains largely under-studied is the production of shotcrete mixes. It is expected that using CWG in shotcrete production would offer the triple benefits of (1) addressing the global geo-environmental and financial challenges of natural and quarried sand depletion, (2) reuse of the ever-increasing waste glass worldwide, and (3) cutting construction costs and improving the sustainability of tunnelling and the mining sectors. With the above motivations in mind, this study assesses the applicability of cullet (CWG) in designing a sustainable shotcrete mix as sand replacement and investigates further how this replacement could affect shotcrete properties. Unconfined compressive strength (UCS), tensile strength, pumpability, workability, fracturing behaviour, early-age and long-term strength, drying shrinkage, and stiffness properties of several shotcrete mixes with glass aggregates were measured, and the results are discussed in this study and compared to those of the reference mixtures. In the following sections, experimental set up are first explained followed by results overview and discussion. Limitations of the study and future directions for research and recommendations are highlighted in the conclusion section.

\section{Experimental set-up}

Over 250 tests with five different mixes of shotcrete with waste glass aggregates replacing sand at proportions of $0 \%, 10 \%, 20 \%, 50 \%$ and $100 \%$ under constant water to binder ratio of 0.45 , were carried out. The raw materials used in this research and their properties are summarised in Table 2. General-purpose (GP) cement was used, and fine river sand with a particle size of $0-0.425 \mathrm{~mm}$, also medium and coarse break stone aggregates with particle size ranges of $0-4.75 \mathrm{~mm}$ and $1.18-9.5 \mathrm{~mm}$, respectively, were adopted (see also Figs. 2 and 3). The crushed waste glass (sourced mainly from food containers and glass bottles) was provided by a local supplier in Brisbane (Enviro Sand, Australia), Flyash (Grade 1) was used as a Supplementary Cementitious Material (SCM), and steel fibres 
(DRAMIX ${ }^{\circledR}$ 3D 65/35BG added at a target fibre content of $35 \mathrm{~kg} / \mathrm{m}^{3}$ ) were added to all mixes to replicate real life mix conditions. In practice, steel fibres are mainly utilised to impart a high degree of ductility and enhance the bearing capacity of the shotcrete, while flyash improves the workability, pumping ability and ability to adhere to the surface. Flyash is further proven to be a cost-effective addition (also improving sustainability) as it reduces the amount of cement used in the shotcrete production. Tytro WR 174 and Tytro HC 270 admixtures - widely used by shotcrete practitioners and producers in Australia's mines and tunnels as high range water reducing (HRWR) and hydrationcontrol chemicals, respectively - were added to all the mixes to enhance the workability and to stabilise hydration. Admixture rates were kept constant as a percentage of the cement weight in all the mixes for consistency. Table 3 shows the final proportions for the reference and the $100 \%$ sand-replaced design mixes.

The moisture content of each of the aggregates and admixtures was first measured (according to AS 1289.2.1.1 recommendations) to determine the volume of free-water in the mix and then to calculate the amount of water needed to reach the target $\mathrm{w} / \mathrm{c}$ (water to cement) ratio of 0.45 in each mix. A carefully designed procedure (after several trials) was then followed to prepare the mixes in a consistent fashion. This included: (1) all the aggregates plus CWG and steel fibres were added and mixed in the mixer for three minutes, (2) the binder materials (cement and flyash) were then added and mixed for three more minutes to homogeneously combine the solid ingredients, (3) water and admixtures were finally added and mixed for another three minutes to achieve a uniform mixture, and (4) the mixture was allowed to rest for a further three minutes before actual testing of the batch. After testing for plastic properties (slump and reverse cone tests), shotcrete samples were cast into moulds and were allowed to rest for $24 \mathrm{~h}$ at room temperature. The samples were then de-moulded and stored in a lime saturated until removal for testing. The temperature of the curing bath was kept at 27 degrees \pm 2 degrees at all times (see also Fig. 1). Cubed samples with $50 \mathrm{~mm}$ in dimension were further prepared to study the strength behaviour of shotcrete mixes under biaxial load combinations. The principal stresses and strains at failure were then recorded using a recently devolved true triaxial testing facility at the Geotechnical Engineering Centre (GEC) within the school of Civil engineering at the University of Queensland (Brisbane, Australia). The system is capable of performing true triaxial loading (up to $850 \mathrm{kN}$ in each direction), permeability, hydraulic fracking, and thermo-mechanical coupled modelling at elevated temperature of up to 100 degrees [26]. The system is also designed to accommodate acoustic emission and ultrasonic monitoring instrumentations to carefully monitor and assess the progressive damage in loaded samples. The mechanical properties, load-deflection curve, and fracture characteristics of the samples were finally investigated at curing periods of 7, 28 and 70 days. The test procedures and standard recommendations followed are listed in Table 4.

\section{Results and discussion}

It should be noted that the reverse cone test was conducted in a similar way to the slump test, but the slump cone was placed up-side-down (slight modification to BS EN 12350-8). Once the shotcrete was placed inside the inverted cone, it was then raised in a vertical direction for 2-4 $\mathrm{s}$ and the diameter of the spread shotcrete was measured (see Table 4). For practical purposes, the spread should be typically in the range of $500-600 \mathrm{~mm}$ within 1.5-2.5 s. The drying shrinkage (DS) specimens consisted of three embedded $75 \times 75 \times 285 \mathrm{~mm}$ bars with studs at each end. The drying shrinkage room was kept at $23 \pm 2$ degrees and $50 \pm 5 \%$ relative humidity at all times. The airflow rate in the test room was measured as $12 \pm 5 \mathrm{ml}$ during the 8 weeks of testing. The two ends of UCS core samples were ground to ensure a uniform and evenly distributed stress was applied to the sample until failure. All the shotcrete mixes were designed to reach an early age strength of $1 \mathrm{MPa}$ in $2 \mathrm{~h}$ and $2.5 \mathrm{MPa}$ in $8 \mathrm{~h}$ as is often needed in practice. Also, apart from the slump test, shotcrete workability of the mixes was calculated by subtracting 100 from the sum of the slump and flow (reverse cone) tests. In addition, when preparing the final $100 \%$ mix, it was realised that the mixture has high workability and segregation was observed at the end of the batching process. It was therefore decided to add TYTRO RC 430 (which is a rheology-control admixture based on nanometric colloidal silica formulated) to pull the shotcrete back together. The admixture was added in three steps with $35 \mathrm{ml}$ in the first step, $35 \mathrm{ml}$ in the second step and $25 \mathrm{ml}$ in the final step. All the results are summarised in Table 5 and Figs. 4 and 6 . From the results, it can be seen that:

- The slump and reverse cone test results both show an increasing trend in the workability and pumpability indices with the addition of glass aggregate to the shotcrete mix. Apart from the $100 \%$ mix (being the only mix with Tytro RC 430 added), slump retention of no less than $140 \mathrm{~mm}$ was further confirmed up to $4 \mathrm{~h}$ after batching in all mixes.

- Density is increased slightly with increased amounts of CWG, but bleeding results have increased considerably which can be explained by the almost zero water absorption property of glass compared to sand. That 
Fig. 1 Test results and the raw materials used in this research project, including a tested UCS samples at $0 \%$ and $50 \%$ sand replacement ratios, $\mathbf{b}$ installation of vertical and radial extensometers to measure the shotcrete stiffness and radial expansion, $\mathbf{c}$ aggregates and binders, $\mathbf{d}$ slump test to measure workability, e reverse cone test to measure pumpability, f end-beam test to assess shotcrete early-age strength, and $\mathbf{g}$ the experimental set-up for testing the samples under biaxial compression

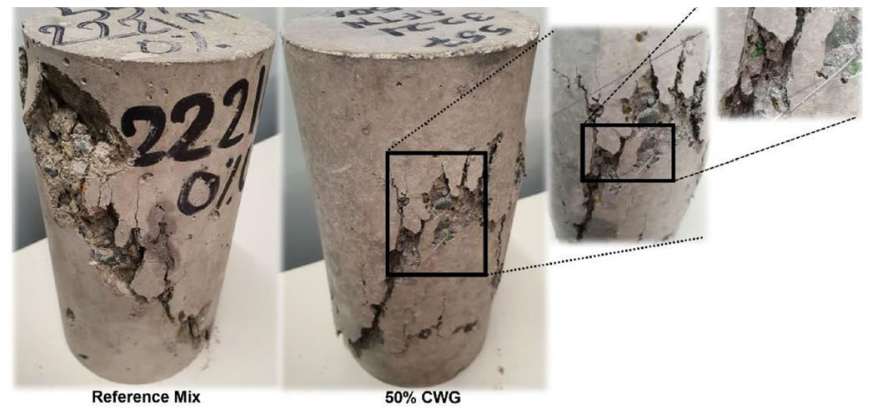

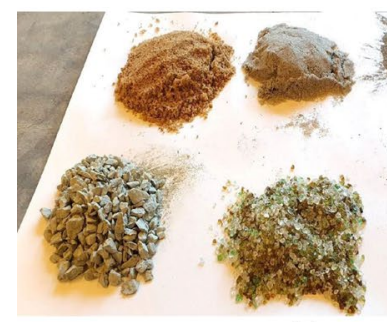

(c)

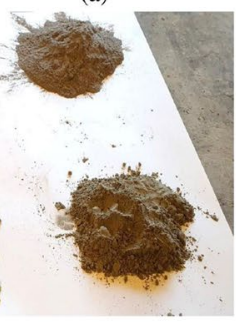

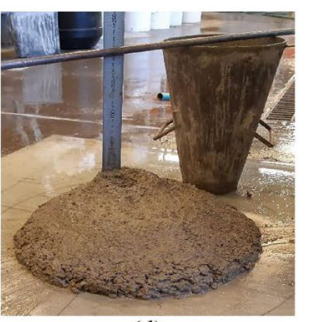

(d)

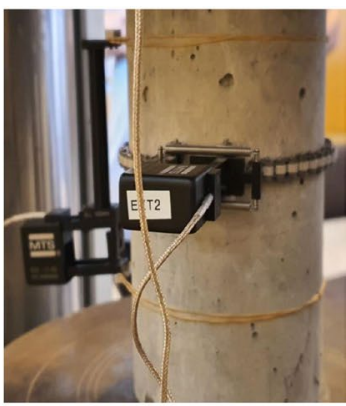

(b)

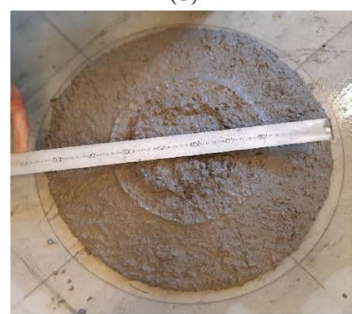

(e)
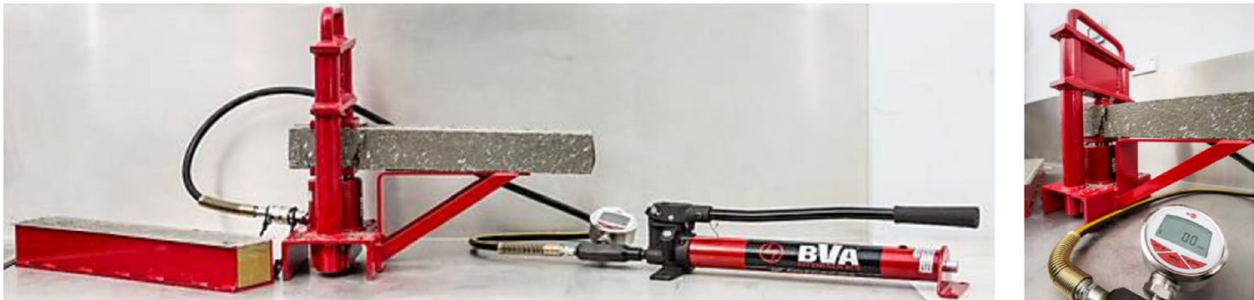

(f)
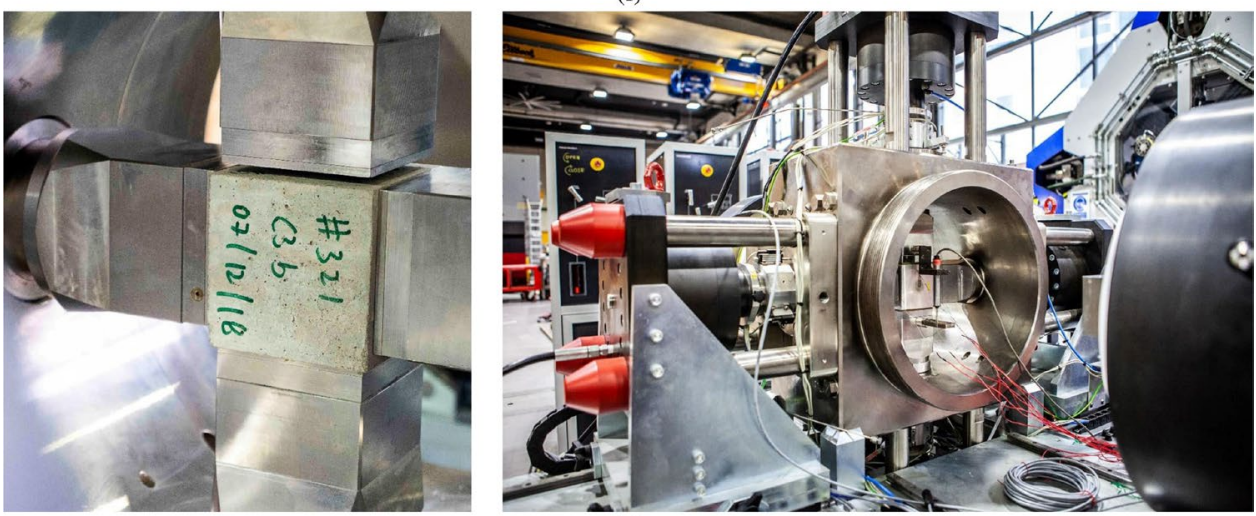

(g) is, bleeding is a phenomenon taking place due to selfweight consolidation of solids in a freshly-placed concrete/shotcrete (in the initial few hours after mixing) that forces the excess water in the mixture to the surface of the sample. The accumulated water (i.e. bleeding) represents the water percentage in the mixture not absorbed by the sand and cement. Therefore, at a constant $\mathrm{w} / \mathrm{c}$ design (as adopted in this study), shotcrete mixtures with aggregates less prone to water absorption are expected to require less water (hence cement) to reach a similar workability index. Also, as explained above, it is worth re-mentioning that TYTRO RC 430 was used during the preparation of the $100 \%$ design (with the highest initial bleed values) to bring the mixture bleed under $4 \mathrm{ml}$-see also Table 5 .

- Air content decreased when more CWG is added which can be attributed to the higher mechanical interlocking of glass aggregates due to its higher angular nature, hence creating less void space in the mix to be filled with trapped air. This observation suggests that there would be an optimum percentage of CWG additive to minimise the air content of the shotcrete.

- The shotcrete early strength gain is typically associated with its water/cement ratio. Generally speaking, the lower the $\mathrm{w} / \mathrm{c}$ ratio, the faster the early hydration rate, hence the greater the early strength of the shotcrete. 
Table 2 Specification of the raw materials-see also [24, 27]

\begin{tabular}{|c|c|c|}
\hline Material & Property & Standard \\
\hline \multirow[t]{6}{*}{ Cement } & Fineness Index: $387\left(\mathrm{~m}^{2} / \mathrm{kg}\right)$ & AS/NZS 2350.8 \\
\hline & Normal Consistency: $27.50 \%$ & AS/NZS 2350.3 \\
\hline & Initial Setting Time: 135 min (Limit 45 mins. Min.) & AS/NZS 2350.4 \\
\hline & Final Setting Time: 190 min (Limit 360 mins. Max.) & AS/NZS 2350.4 \\
\hline & Soundness: $0 \mathrm{~mm}$ & AS/NZS 2350.5 \\
\hline & $\begin{array}{l}\text { Mortar 3, } 7 \text { and 28-days Compressive Strength: } 35.8 \\
\mathrm{MPa}, 47.9 \mathrm{MPa} \text {, and } 66.8 \mathrm{MPa}\end{array}$ & AS/NZS 2350.11 \\
\hline \multirow[t]{3}{*}{ Flyash } & Specific Gravity: 2 & AS 3583.5 \\
\hline & Fineness @ 45 micron: 86\% (Limit 75\% Minimum) & AS 3583.1 \\
\hline & Moisture Content: <0.1\% (Limit 0.5\% maximum) & AS 3583.2 \\
\hline \multirow[t]{6}{*}{ Steel fibre } & Length \& Diameter: $35 \mathrm{~mm} \& 0.55 \mathrm{~mm}$ & \\
\hline & Aspect Ratio(l/d): 65 & \\
\hline & Young's modulus: $210 \mathrm{MPa}$ & \\
\hline & Strain at ultimate strength: $0.80 \%$ Nominal & \\
\hline & Tensile Strength: $1.345 \mathrm{MPa}$ & \\
\hline & Made of cold-drawn wire with shape-hooked ends & \\
\hline \multirow[t]{7}{*}{ Sand } & Apparent Particle Density: $2.65\left(\mathrm{t} / \mathrm{m}^{3}\right)$ & AS 1141.5 \\
\hline & Particle Density-DRY: $2.62\left(\mathrm{t} / \mathrm{m}^{3}\right)$ & AS 1141.5 \\
\hline & Particle Density-SSD: $2.63\left(\mathrm{t} / \mathrm{m}^{3}\right)$ & AS 1141.5 \\
\hline & Water Absorption: $0.40 \%$ & AS 1141.5 \\
\hline & Clay and Fine Silt: 3\% & AS 1141.33 \\
\hline & Particle Size Range: 0-0.425 mm & AS 1141.11 .1 \\
\hline & Sample Source: Moreton Bay, QLD & \\
\hline \multirow[t]{7}{*}{ Medium Sand } & Apparent Particle Density: $2.63\left(\mathrm{t} / \mathrm{m}^{3}\right)$ & AS 1141.5 \\
\hline & Particle Density-Dry: $2.56\left(\mathrm{t} / \mathrm{m}^{3}\right)$ & AS 1141.5 \\
\hline & Particle Density-SSD: $2.59\left(\mathrm{t} / \mathrm{m}^{3}\right)$ & AS 1141.5 \\
\hline & Water Absorption: $1.00 \%$ & AS 1141.5 \\
\hline & Clay and Fine Silt: $8 \%$ & AS 1141.33 \\
\hline & Particle Size Range: 0-4.75 mm & AS 1141.11 .1 \\
\hline & Sample Source: Rockwell quarry, QLD & \\
\hline \multirow[t]{7}{*}{$7 \mathrm{~mm}$ Aggregates } & Apparent Particle Density: $2.97\left(\mathrm{t} / \mathrm{m}^{3}\right)$ & AS 1141.6.1 \\
\hline & Particle Density-Dry: $2.92\left(\mathrm{t} / \mathrm{m}^{3}\right)$ & AS 1141.6.1 \\
\hline & Particle Density-SSD: $2.94\left(\mathrm{t} / \mathrm{m}^{3}\right)$ & AS 1141.6.1 \\
\hline & Water Absorption: $0.60 \%$ & AS 1141.6.1 \\
\hline & Flakiness Index: 29\% & AS 1141.6.1 \\
\hline & Particle Size Range: 1.18-9.5 mm & AS 1141.11 .1 \\
\hline & Sample Source: Blue Rock Quarry, QLD & \\
\hline \multirow[t]{10}{*}{ Crushed Waste Glass (CWG) } & Specific Gravity: 2.5 & ASTM D5550-14 \\
\hline & Particle Size Range: 1.25-4.30 (mm) & AS 1141.11 .1 \\
\hline & Maximum Dry-Density: $1.82\left(\mathrm{t} / \mathrm{m}^{3}\right)$ & AS1141.5 \\
\hline & Minimum Dry-Density: $1.39\left(\mathrm{t} / \mathrm{m}^{3}\right)$ & AS1141.5 \\
\hline & Abrasion Loss: $2.40 \%$ & ASTM D7428 \\
\hline & $\begin{array}{l}\text { Maximum Void Ratio: } 0.79 \\
\text { Minimum Void Ratio: } 0.37\end{array}$ & - \\
\hline & Roundness index: 0.32 & - \\
\hline & $\mathrm{SiO}_{2}$ content using XRF spectroscopy: $72.07 \%$ & - \\
\hline & Acid Solubility: $<1 \%$ & - \\
\hline & Crystalline Silica: $<1 \%$ & - \\
\hline
\end{tabular}


Table 3 Mix design for the reference and the 100\% sand-replaced mixes for preparing 85 litres of shotcrete

\begin{tabular}{lll}
\hline Material & Reference mix & $100 \%$ CWG \\
\hline 7 mm aggregates & $38.10 \mathrm{~kg}$ & $38.10 \mathrm{~kg}$ \\
Sand & $86.42 \mathrm{~kg}$ & - \\
Fine sand & $13.01 \mathrm{~kg}$ & $13.01 \mathrm{~kg}$ \\
CWG & - & $85.00 \mathrm{~kg}$ \\
Cement & $29.33 \mathrm{~kg}$ & $29.33 \mathrm{~kg}$ \\
Flyash & $9.78 \mathrm{~kg}$ & $9.78 \mathrm{~kg}$ \\
Steel fibres & $2.98 \mathrm{~kg}$ & $2.98 \mathrm{~kg}$ \\
Added water & $15.78 \mathrm{~kg}$ & $17.15 \mathrm{~kg}$ \\
\hline
\end{tabular}

But, given this ratio was kept constant in all the mixes in this study, no apparent change in the shotcrete earlyage strength was observed even at up to $100 \%$ sand replaced with glass aggregates (see Fig. 4a). However, after $5 \mathrm{~h}$ from batching, the highest shotcrete strength was reached with the $20 \%$ CWG mix at $2.25 \mathrm{MPa}$.

- Glass inclusion in concrete production has proven to introduce a water-reducing effect owing to the glass surface structure. This effect can also be seen readily in the results of drying shrinkage tests as illustrated in Fig. 4b. With reference to the figure, it is clear that the contraction of a hardened shotcrete mix (due to the loss of its capillary water) decreases with a higher percentage of CWG inclusion. This observation is practically very important as the adverse effect of shotcrete shrinkage over time may lead to cracking, internal warping, and external deflection before the mixture is subjected to any kind of external loading. That is, the improved shrinkage characteristics in shotcrete mixes with sand replaced with higher percentages of glass aggregates would make the mix less susceptible to probable shrinkage movement and subsequent cracking in practice.

- There were hardly any differences observed in the stiffness and Poisson's ratio in all the mixes. This can be explained by the similar mechanical properties of CWG and sand at a particle scale (see also Figs. $4 \mathrm{c}$ and $4 \mathrm{~d}$ ). All mixes, however, demonstrated a steady increase of shotcrete stiffness over time.

- More interestingly, no significant change can be observed for the mechanical strengths up to 70-days between the control and all the new CWG mix designs. It can be seen that the tensile strength and UCS results only varied by around $10 \%$, with the exemption of the $100 \%$ mix in which the combined PSD (particle size distribution) of the mix was found more coarse than the reference mix hence potentially not allowing a complete packing of the materials and the bonding interface with the steel fibres (see also Fig. 5). It was decided that additional mix design alterations need

Table 4 List of the tests conducted and their corresponding standards

\begin{tabular}{|c|c|c|}
\hline Test type & Standards & Comments \\
\hline Slump Test & AS 1012.3 .1 & $\begin{array}{l}\text { To determine shotcrete workability. An initial Slump of } 180-220 \mathrm{~mm} \text { is often needed in prac- } \\
\text { tice }\end{array}$ \\
\hline Slump Retention & AS 1012.3.1 & $\begin{array}{l}\text { To determine retention of the shotcrete workability by repeating the slump test at several } \\
\text { time intervals of } 1 \mathrm{~h}, 2 \mathrm{~h} \text {, and } 4 \mathrm{~h} \text { after batching. Workability retention of } 3 \mathrm{~h} \text { minimum is } \\
\text { often needed in practice }\end{array}$ \\
\hline Reverse Cone & BS EN 12350-8 & To measure shotcrete pumpability, flowability and its capacity to run freely down a slickline \\
\hline Air content & AS 1012.4:2014 & $\begin{array}{l}\text { To measure the amount of air entrained in shotcrete. It can determine whether the mix is pro- } \\
\text { tected from freeze-thaw conditions or is prone to weathering, and can affect the finish and } \\
\text { cosmetic look of the shotcrete. The mix should not contain air content greater than } 3 \%\end{array}$ \\
\hline Density & AS 1012.5:2014 & To gauge shotcrete solidity \\
\hline Bleed Rate & AS 1012.6:2014 & $\begin{array}{l}\text { To describe the separation of water from a shotcrete mix due to the settlement of its solid } \\
\text { materials }\end{array}$ \\
\hline End Beam Test & AS 1012.3.1 & $\begin{array}{l}\text { To measure early-age strength of a shotcrete mix using a manually operated hydraulic ram as } \\
\text { shown in Fig. } 1\end{array}$ \\
\hline Compressive Strength & AS 1012.9:2014 & To estimate the unconfined compressive strength (UCS) of shotcrete \\
\hline Brazilian Test & AS 1012.8.1:2014 & $\begin{array}{l}\text { To indicate tensile strength of shotcrete and its cracking resistance under induced tensile } \\
\text { stresses }\end{array}$ \\
\hline Dry Shrinkage (DS) & AS 1012.13:2015 & $\begin{array}{l}\text { To gauge the contraction of shotcrete due to loss of water/moisture content by measuring } \\
\text { the shortening of DS samples from a water-saturated condition at the age of 7-days for vari- } \\
\text { ous periods of drying up to } 8 \text { weeks }\end{array}$ \\
\hline High Speed Photography & - & To identify fracture patterns, cracking mode and crack growth mode in shotcrete mixes \\
\hline Elastic Properties & AS 1012.17 & $\begin{array}{l}\text { To calculate the elastic properties of a shotcrete mix including stiffness modulus and Passion's } \\
\text { ratio }\end{array}$ \\
\hline
\end{tabular}




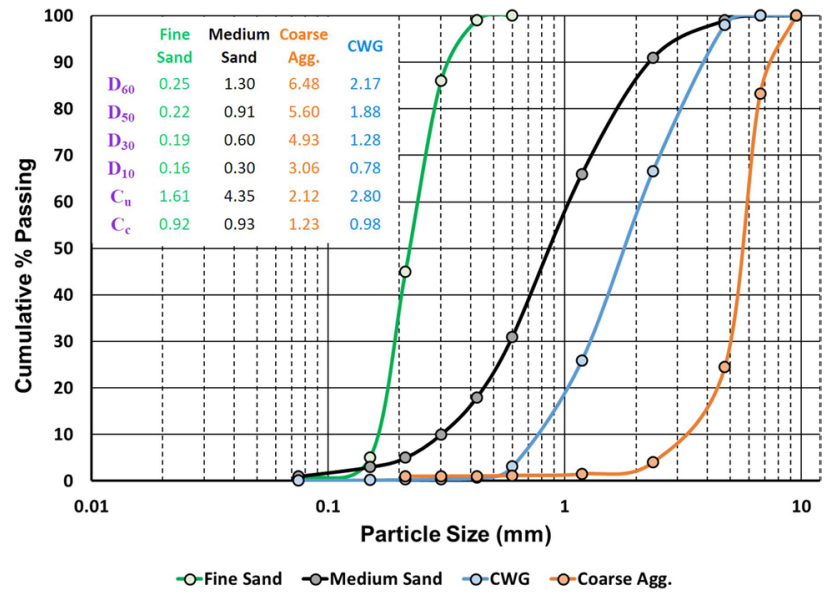

Fig. 2 Gradation curves of the materials used in this study. The uniformity coefficient $\left(C_{u}\right)$ and the coefficient of gradation $\left(C_{c}\right)$ are the measures of sand/CWG gradation defined as $D_{60} / D_{10}$ and $D_{30}{ }^{2} /$ $\left(D_{60} D_{10}\right)$, respectively. Also, $D_{x}$ relates to the portion of particles with diameters smaller than $\mathrm{x} \%$

to be considered other than the percentage of sand replacement. Nevertheless, the brittleness index, i.e. the ratio of UCS/tensile strength [28], is the same for different mixes despite glass being a relatively more brittle material than sand.

- It has been reported that the fracture mode in the Brazilian test is primarily controlled by the material's brittleness index. That is, in solids with a high brittleness index and a large tensile strength, it becomes more likely to observe an explosion-like failure in the form of multiple cracking and large secondary shear fractures during the Brazilian test [29]. However, given the brittleness index in all the shotcrete mixes was similar (see the point above), further high-speed photography recordings (at $200 \mathrm{kHz}$ and above) of the tensile cracking in CWG mixes didn't pick-up any significant changes in terms of the fracture mode and the cracking speed. However, image processing of the high speed video recordings identified three discrete fracturing patterns. These were (i) a single straight central crack initiated at the sample centre, (ii) a central tensile crack accompanied by small boundary cracks (mostly shear), and (iii) a fracture propagation mode where a central crack begins at one of the two loading points (instead of the sample's centre) and forms a straight fracture surface. While fracture type (i) above was the predominant failure mode observed in over $80 \%$ of all the Brazilian tests conducted, no direct link between the fracture mode and the shotcrete mix was verified after further careful investigations (see also Fig. 6a). A possible reason for this could be the existence of steel fibres in all the mixes that could have largely controlled the fracture propagation mode in the failed samples after the formation of initial cracks hence making the fracturing pattern independent of the mix design.

- The ultimate strength of all mixes under biaxial compression is always higher than under uniaxial compression. However, the control mix design with no waste glass aggregate shows the weakest shotcrete mix, meaning that the inclusion of CWG has a positive effect on the load bearing capacity of shotcrete under biaxial stress combinations. The maximum biaxial strength occurred with the $20 \%$ sand replacement mix at $\sigma_{2}$ equals to around $50 \%$ of the mixture UCS.

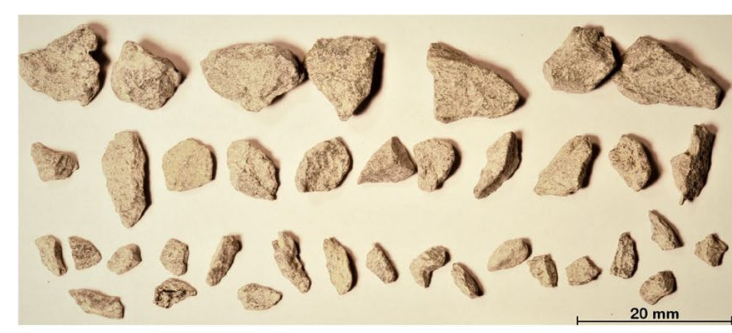

Coarse Aggregate

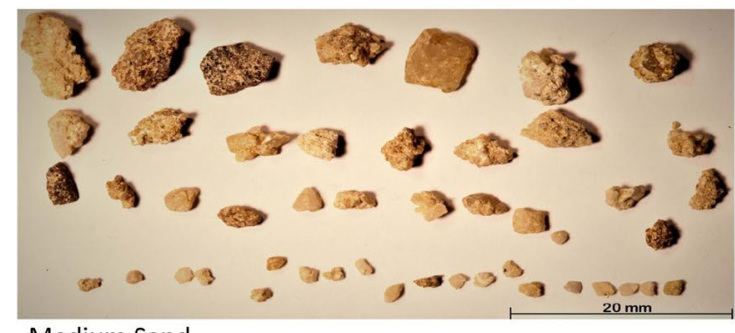

Medium Sand

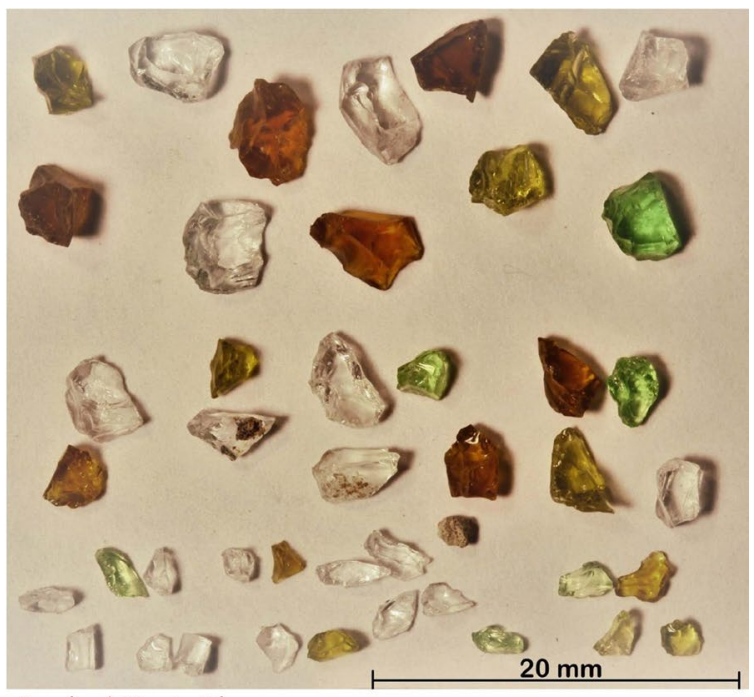

Crushed Waste Glass

Fig. 3 Photographs of the aggregates' size and shape used in this study 


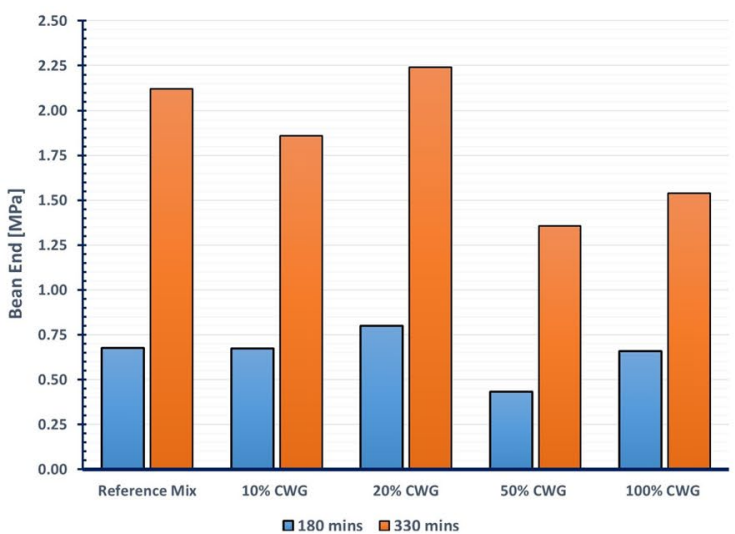

(a)

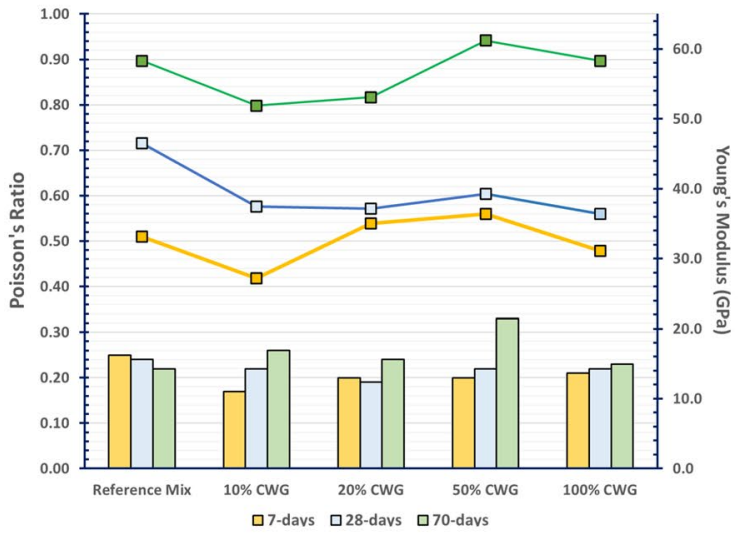

(c)

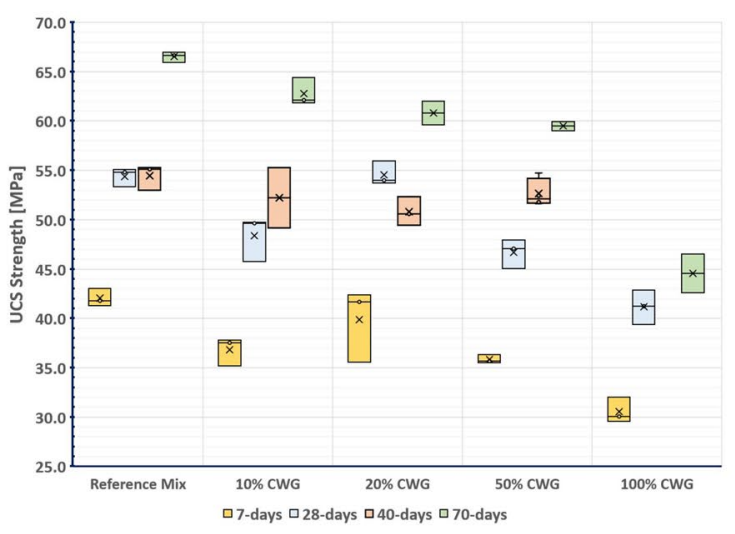

(e)

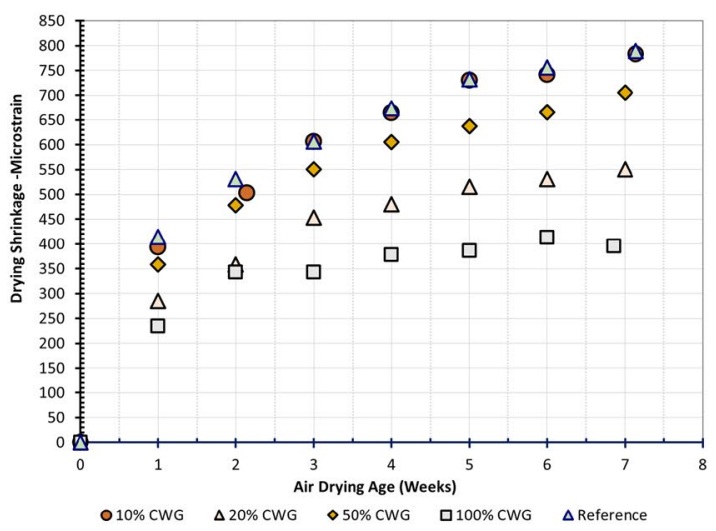

(b)

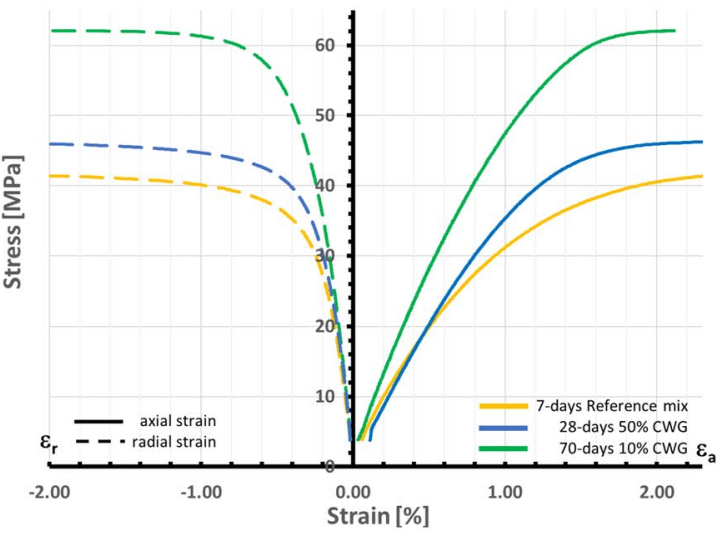

(d)

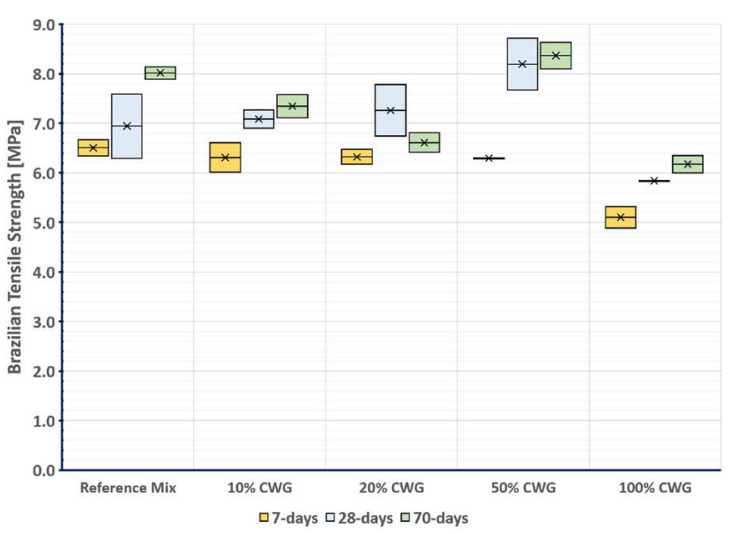

(f)

Fig. 4 Influence of sand replacement with glass aggregates on shotcrete properties, including its a early-age strength, b drying shrinkage, c elastic properties, $\mathbf{d}$ stress-strain behaviour, e unconfined compressive strength, and $\mathbf{f}$ tensile strength

In order to evaluate if the replacement of sand with CWG makes a significant impact on shotcrete properties (i.e. to accept or reject this null hypothesis), a statistical methodology commonly referred to as the Analysis of Variance (ANOVA) was carried out. The ANOVA method was developed in the early 1920s by Ronald Fisher, and is based on partitioning of the total variability in the response variable into components that are consistent with an underlying model for the experiment [30]. A typical model often used for a single-factor ANOVA test is in the form of Eq.1, in which $y_{i j}$ is the $j^{\text {th }}$ observation of the 
Table 5 Summary of the basic properties in all the tested shotcrete mixes

\begin{tabular}{llllll}
\hline Test type & Reference mix & $10 \%$ & $20 \%$ & $50 \%$ & $100 \%$ \\
\hline Slump (mm) & 235 & 255 & 240 & 265 & 200 \\
Slump (mm) after 1 h & 200 & 250 & 225 & 225 & 165 \\
Slump (mm) after 2 h & 175 & 235 & 190 & 230 & 115 \\
Slump (mm) after 3 h & 160 & 220 & 165 & 220 & - \\
Reverse Cone (mm) & 460 & 560 & 475 & 600 & - \\
Workability Index & 595 & 715 & 615 & 765 & - \\
Density $\left(\mathrm{kg} / \mathrm{m}^{3}\right)$ & 2663.09 & 2974.14 & 2985.27 & 2977.85 & 2874.01 \\
Air content $(\%)$ & 1.2 & 0.8 & 0.6 & 0.4 & 3.5 \\
Bleed $(\mathrm{ml})$ & 0 & 4 & 4 & 12 & 3 \\
Tensile crack speed $(\mathrm{m} / \mathrm{s})$ & 1.23 & 0.92 & 1.56 & 1.37 & 0.67 \\
\hline
\end{tabular}

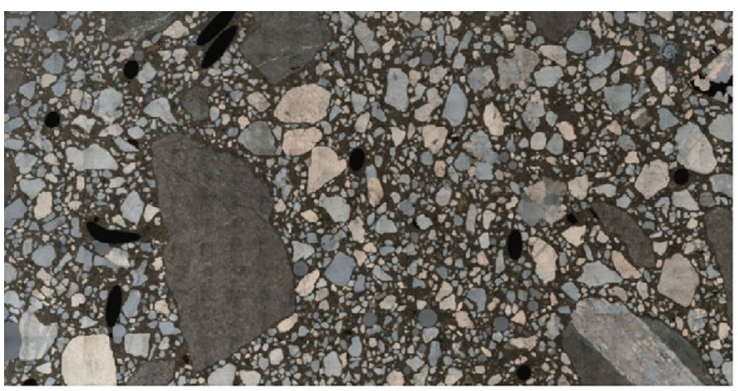

(a)

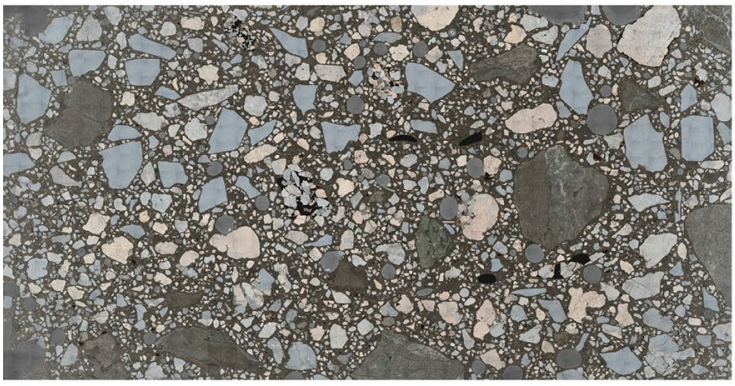

(c)

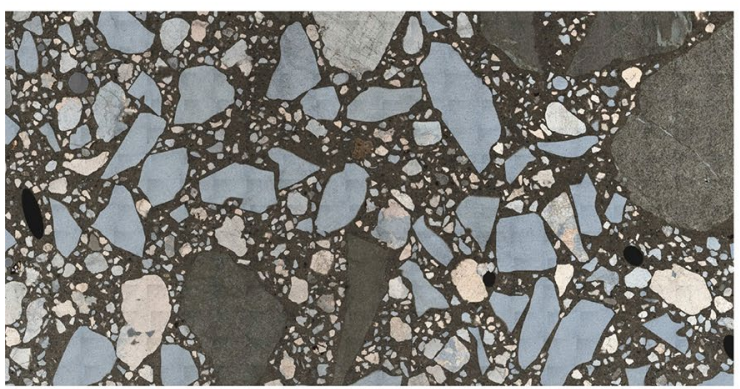

(e)

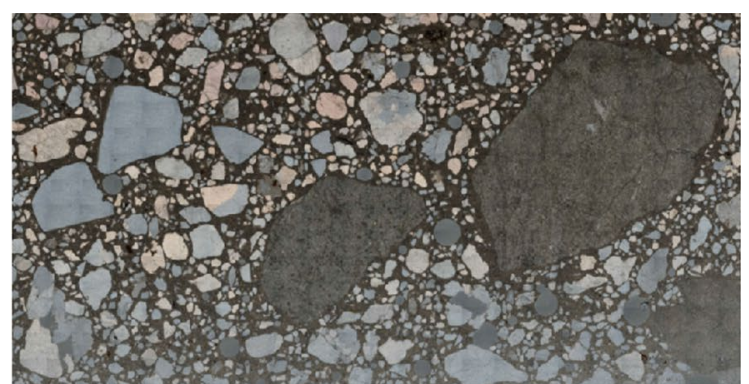

(b)

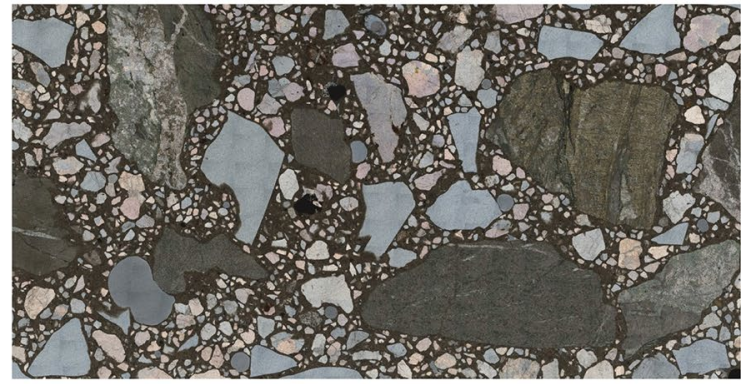

(d)

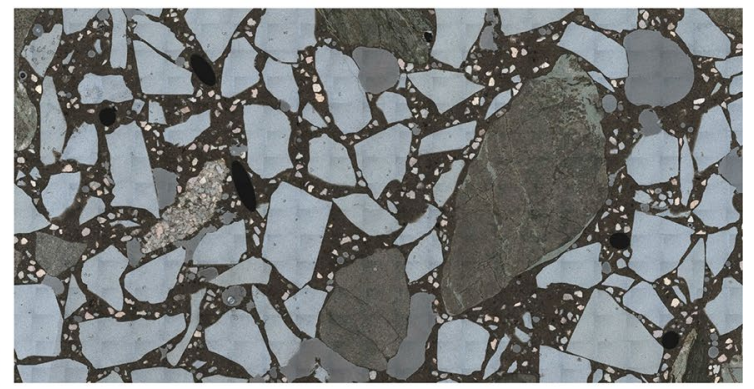

(f)

Fig. 5 Analysis of thin sections obtained from shotcrete mixes with $0 \%, 10 \%, 15 \%, 20 \%, 50 \%$ and $100 \%$ sand replaced with glass aggregates from (a) to (f), respectively

$i^{\text {th }}$ treatment, $\mu$ is the total average for all the observations in the experiment, $\tau_{i}$ is the effect of the $i^{\text {th }}$ treatment, and $\epsilon_{i j}$ is the random error term which is assumed to have a standard normal distribution with a constant variance of $0<\sigma^{2}$. In other words, Eq. 1 assumes that a different mean 
Fig. 6 a High-speed timelapses of the fracture pattern observed in Brazilian shotcrete samples (captured at 120,000 frames per second) compressed between at horizontal platens according to ASTM recommendations, and b Biaxial strength results for different types of shotcrete mixes under biaxial compressions

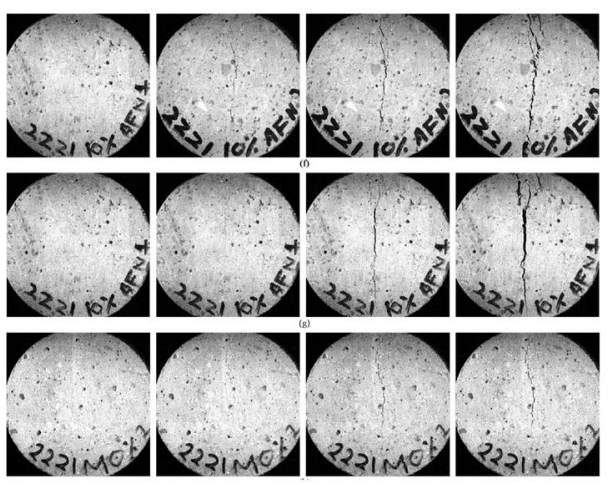

(a)

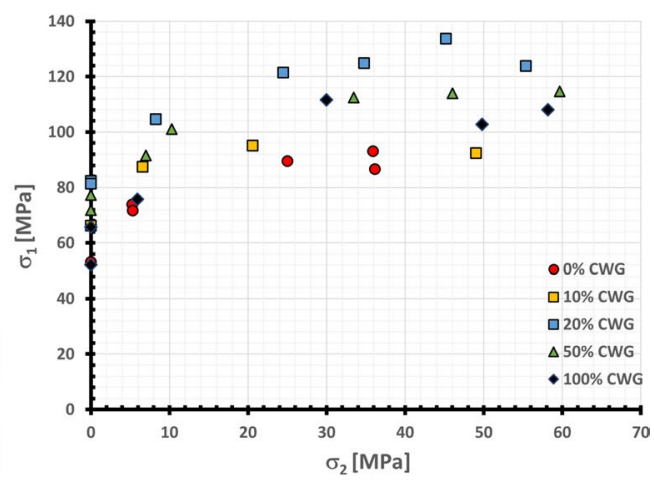

(b) for the ith treatment is not due to the treatments related to different populations but rather caused by a different treatment effect $\tau_{i}$.

$$
\begin{aligned}
y_{i j} & =\mu+\tau_{i}+\epsilon_{i j} \\
i & =1,2,3, \ldots, \text { a number of treatments } \\
j & =1,2,3, \ldots, \text { n number of observations per treatment }
\end{aligned}
$$

While other statistical testing methods exist, a one-way (single-factor) ANOVA test was referred since the only factor investigated in this study is the CWG ratio at different levels (treatments) of $0 \%, 10 \%, 20 \%, 50 \%$ and $100 \%$. To minimises the probability of committing a Type II error, each factor level was designed to have equal sample sizes of a minimum of three (3) replications. Results of the ANOVA analysis with a small P-value (typically less than $5 \%$ significance level) reject the null hypothesis mentioned above. Alternatively, one can calculate the F-number in ANOVA defined as the ratio of the variation between a target property in all shotcrete mixes to the variation within each shotcrete mix. When the calculated F-statistic is less than the critical F-ratio (corresponding to the target P-value), it is concluded that there is not a significant amount of variation in the target shotcrete property caused by sand replacement with CWG. If the null hypothesis is rejected, however, the alternative hypothesis is considered that at least one shotcrete mix has a significantly different variance. In this case, a Tukey comparison can be conducted further to determine which of the sample means (shotcrete mixes) are different. A detailed discussion of the ANOVA and Tukey test is beyond the scope of this paper and interested readers are referred to [30]. To perform the ANOVA test, SAS JMP program was utilised. The results are shown in Tables 6, 7 and 8 for the UCS and Brazilian tensile strength data points. A significance level of 0.05 was considered and equal variances were assumed, given ANOVA becomes insensitive to departures from the assumption of equal variances if the sample size for factor levers are equal. Nevertheless, to test for homogeneity of variances and to check normality of residuals as the two key assumptions in ANOVA, further quantile plots of residuals and Bartlett tests were performed before each ANOVA analysis.

According to Tables 6-8, it can be seen that there are statistically significant differences (where P-value is less than 0.05 ) between the $100 \%$ mix design and the reference (control) mixture in both the UCS and Brazilian tests results. However, up to $50 \%$ sand replacement with glass waste produces approximately similar tensile and compressive strength in all other shotcrete mix designs. The
Table 6 ANOVA Test Results for the Brazilian tests

\begin{tabular}{lllllll}
\hline & Source of Variation & Sum of Squares & $\begin{array}{l}\text { Degrees of } \\
\text { Freedom }\end{array}$ & Mean Square & $F_{o}$ & $f P$ value \\
\hline 7-days & CWG Ratio & 2.5763111 & 4 & 0.644078 & 8.8113 & 0.0174 \\
& Error & 0.3654830 & 5 & 0.073097 & & \\
& Total & 2.9417941 & 9 & & & \\
\multirow{5}{*}{ 28-days } & CWG Ratio & 5.6569727 & 4 & 1.41424 & 3.5358 & 0.0993 \\
& Error & 1.9998936 & 5 & 0.39998 & & \\
& Total & 7.6568663 & 9 & & & \\
70-days & CWG Ratio & 6.7955513 & 4 & 1.69889 & 19.8796 & 0.0029 \\
& Error & 0.4272945 & 5 & 0.08546 & & \\
& Total & 7.2228458 & 9 & & & \\
\hline
\end{tabular}


Table 7 ANOVA Test Results for the UCS tests

\begin{tabular}{lllllll}
\hline & Source of Variation & Sum of Squares & $\begin{array}{l}\text { Degrees of } \\
\text { Freedom }\end{array}$ & Mean Square & $F_{\mathbf{0}}$ & $P$ value \\
\hline 7-days & CWG Ratio & 229.53121 & 4 & 57.3828 & 15.3186 & 0.0003 \\
& Error & 37.45951 & 10 & 3.7460 & & \\
& Total & 266.99072 & 14 & & & \\
\multirow{2}{*}{ 28-days } & CWG Ratio & 380.25358 & 4 & 95.0634 & 37.6926 & $<0.0001$ \\
& Error & 25.22073 & 10 & 2.5221 & & \\
& Total & 405.47431 & 14 & & & \\
70-days & CWG Ratio & 629.01072 & 4 & 157.253 & 71.3217 & $<0.0001$ \\
& Error & 15.43385 & 10 & 2.205 & & \\
& Total & 644.44457 & 14 & & & \\
\hline
\end{tabular}

Table 8 Tukey comparisons for the UCS and Brazilian test results

\begin{tabular}{|c|c|c|c|c|c|c|c|}
\hline \multirow[t]{2}{*}{ Level } & \multirow[t]{2}{*}{ Level } & \multicolumn{3}{|c|}{$P$ value for the Brazilian tests } & \multicolumn{3}{|c|}{$P$ value for the UCS tests } \\
\hline & & 7-days & 28-days & 70-days & 7-days & 28-days & 70-days \\
\hline Reference Mix & $100 \%$ CWG & 0.0180 & 0.4875 & 0.0078 & 0.0002 & $<0.0001$ & $<0.0001$ \\
\hline $20 \%$ CWG & $100 \%$ CWG & 0.0319 & 0.2972 & 0.6091 & 0.0011 & $<0.0001$ & $<0.0001$ \\
\hline $10 \%$ CWG & $100 \%$ CWG & 0.0333 & 0.3922 & 0.0502 & 0.0176 & 0.0017 & $<0.0001$ \\
\hline $50 \%$ CWG & $100 \%$ CWG & 0.0350 & 0.0658 & 0.0036 & 0.0465 & 0.0114 & $<0.0001$ \\
\hline Reference Mix & $50 \%$ CWG & 0.9256 & 0.3872 & 0.7572 & 0.0186 & 0.0010 & 0.0077 \\
\hline Reference Mix & $10 \%$ CWG & 0.9414 & 0.9992 & 0.2811 & 0.0494 & 0.0065 & 0.0928 \\
\hline Reference Mix & $20 \%$ CWG & 0.9530 & 0.9836 & 0.0244 & 0.6542 & 1.0000 & 0.0235 \\
\hline $20 \%$ CWG & $50 \%$ CWG & 1.0000 & 0.6129 & 0.0096 & 0.1542 & 0.0009 & 0.8857 \\
\hline $10 \%$ CWG & $50 \%$ CWG & 1.0000 & 0.4816 & 0.0826 & 0.9666 & 0.6914 & 0.2102 \\
\hline $20 \%$ CWG & $10 \%$ CWG & 1.0000 & 0.9983 & 0.2229 & 0.3657 & 0.0055 & 0.6232 \\
\hline
\end{tabular}

promising results discussed above and depicted in Fig. 4 suggest high applicability of cullet re-use in sustainable shotcrete design. It can therefore be concluded that glass utilisation to replace sand not only can improve shotcrete workability and pumpability (without negatively impacting shotcrete mechanical strength properties), but also reduces the amount of cement (and water) needed at a constant $\mathrm{w} / \mathrm{c}$ design; mainly owing to the water-reducing effect and glass surface properties that don't attract water in fresh shotcrete. Further large-scale field testing, which is underway by the authors, is needed to develop specifications for the manufacture of recycled crushed waste glass as an engineering material for use in shotcrete production in large volumes.

\section{Conclusions}

The increasing price and diminishing reserves of natural sand and aggregates signify the urgency to develop a cost-effective and eco-friendly alternative. The everincreasing amounts of waste glass stockpiled worldwide could offer a potential solution to this dilemma. In this study, crushed waste glass was used in shotcrete production to replace sand at varying percentages up to $100 \%$. According to the experimental results, no impairment of performance was recorded by substituting sand with CWG. Utilisation of glass aggregates in shotcrete mixes could, therefore, not only help to conserve precious sand resources and promote closed-loop recycling of waste glass, but will also produce a cheaper product (without negatively impacting shotcrete mechanical strength properties), provide energy savings, and reduce the carbon footprint in the excavation industry by cutting back on the consumption of natural and quarried sand and cement. However, despite the very promising outcomes, further research is needed to understand how glass aggregate inclusion can impact Alkali-Silica Reaction (ASR) property of shotcrete mixes, their thermomechanical strength under coupled biaxial and true triaxial field stresses, and their fire-induced spalling strength under external heat sources, e.g when there is a fire in tunnel. Extension of the results to large scale and field trials are also needed; which is currently underway by the author group. Such further studies and analyses would provide a more fundamental understanding of CWG inclusion in shotcrete mixtures under real field conditions. 
Acknowledgements The authors would like to thank GCP Applied Technologies (Sydney, Australia) for the supply of raw materials, and Mr Paul Howard (Enviro Sand, Australia) for supplying the crushed waste glass used in this study. We are also grateful to Mr Sasan Moravej, Mr Haoyi Hu, Mr Danish Kazmi, and Mr Shane Walker at the School of Civil Engineering at The University of Queensland (Brisbane, Australia) for their assistance with the preparation and testing of shotcrete mixes.

Funding The authors did not receive support from any organization for the submitted work.

\section{Declarations}

Conflict of interest On behalf of all authors, the corresponding author states that there is no conflict of interest. The authors have no competing interests to declare that are relevant to the content of this article

Open Access This article is licensed under a Creative Commons Attribution 4.0 International License, which permits use, sharing, adaptation, distribution and reproduction in any medium or format, as long as you give appropriate credit to the original author(s) and the source, provide a link to the Creative Commons licence, and indicate if changes were made. The images or other third party material in this article are included in the article's Creative Commons licence, unless indicated otherwise in a credit line to the material. If material is not included in the article's Creative Commons licence and your intended use is not permitted by statutory regulation or exceeds the permitted use, you will need to obtain permission directly from the copyright holder. To view a copy of this licence, visit http://creativecommons. org/licenses/by/4.0/.

\section{References}

1. Meany P (2018) More to come from the infrastructure boom. Livewire Markets, pp 14-23

2. Australian Shotcrete Society. Recommended practice - Shotcreting in Australia. Concrete Institute of Australia, 3rd edition (2020)

3. Beaupré $D$ (1994) Rheology of high performance shotcrete. University of British Columbia, Canada

4. Kumar MH, Mohanta NR, Samantaray S, Kumar NM (2021) Combined effect of waste glass powder and recycled steel fibers on mechanical behavior of concrete. SN Appl Sci 3(350)

5. American Concrete Institute. $\mathrm{ACl} 506.4 \mathrm{r}-04$ guide for the evaluation of shotcrete. ACl Committee 506 (1994)

6. EFNARC Sprayed Concrete Technical Committee. European federation of producers and applicators of specialist products for structures. European specification for sprayed concrete (1996)

7. British Standards Institution. Sprayed concrete definitions, specifications and conformity. BS EN 14487-1 (2005)

8. British Standards Institution. Sprayed concrete. part 2: Execution. BS EN 14487-2 (2006)

9. Thomas Alun (2009) Sprayed concrete lined tunnels-An introduction. Taylor \& Francis Group, London \& New York

10. Newman J, Choo BS (eds) (2003) Advanced concrete technology 3: processes. Butterworth-Heinemann, Great Britain

11. Nobre J, Bravo M, de Brito J, Duarte G (2020) Durability performance of dry-mix shotcrete produced with coarse recycled concrete aggregate. J Build Eng 29:101135
12. Luodes H, Kauppila PM, Luodes N, Aatos S, Kallioinen J, Luukkanen S, Aalto J (2012) Characteristics and the environmental acceptability of the natural stone quarrying waste rocks. Bull Eng Geol Environ 71:257-261

13. Hossain Md, Poon CS, Lo I, Cheng JCP (2016) Comparative environmental evaluation of aggregate production from recycled waste materials and virgin sources by LCA. Resour Conserv Recycl 109:67-77

14. Ludacer R (2018) The world is running out of sand - and there's a black market for it now. businessinsider

15. Beiser V (2018) The World in a grain: the story of sand and how it transformed civilization. Riverhead Books, New York

16. Peyronnard O, Benzaazoua M (2011) Estimation of the cementitious properties of various industrial by-products for applications requiring low mechanical strength. Resour Conserv Recycl 56(1):22-33

17. Shi C, Zheng K (2007) A review on the use of waste glasses in the production of cement and concrete. Resour Conserv Recycl 52(2):234-247

18. Fily-Paré I, Jolin M (2013) The use of recycled glass in shotcrete. Shotcrete Mag 15(4):14-16

19. Kaza S, Yao LC, Bhada-Tata P, Van Woerden F (2018) What a Waste 2.0: a global snapshot of solid waste management to 2050. Urban Development, World Bank, Washington

20. Schandl H, King S, Walton A, Kaksonen AH, Tapsuwan S, Baynes TM (2020) National circular economy roadmap for plastics, glass, paper and tyres. CSIRO, Australia

21. Khatib JM, Herki BA, Kenai S (2013) Capillarity of concrete incorporating waste foundry sand. Constr Build Mater 47:867-871

22. Banthia N, Chan C (2000) Use of recycled aggregate in plain and fibre-reinforced shotcrete. Concr Int 22(6):41-45

23. Bhardwaj B, Kumar P (2017) Waste foundry sand in concrete: a review. Constr Build Mater 156:661-674

24. Kazmi D, Serati M, Williams DJ, Sadaf Q, Cheng YP (2021) The potential use of crushed waste glass as a sustainable alternative to natural and manufactured sand in geotechnical applications. J Clean Prod 284:124762

25. Imbabi MS, Carrigan C, McKenna S (2012) Trends and developments in green cement and concrete technology. Int J Sustain Built Environ 47:194-216

26. Serati M, Mutaz E, Williams DJ, Karlovsek J.O.S. Quintero, Hanzic L (2020) Failure mode of concrete under polyaxial stresses. In: Proceedings of the 54th US Rock Mechanics/Geomechanics Symposium, pages ARMA-2020-1141. American Rock Mechanics Association

27. Sand Enviro (2022) Industry's green ingredient

28. Serati M, Alehossein H, Williams DJ (2013) 3D elastic solutions for laterally loaded discs: generalised Brazilian and point load tests. Rock Mech Rock Eng 47(4):1087-1101

29. Serati $M$, Bahaaddini $H$, Roshan T, Zhang, Bryant N (2021) On assessing the tensile cracking pattern in brittle rocks and solids. Bull Eng Geol Environ 80:5867-5879

30. Montgomery DC, Runger GC (2018) Applied statistics and probability for engineers, 7th edn. Wiley, Hoboken

Publisher's Note Springer Nature remains neutral with regard to jurisdictional claims in published maps and institutional affiliations. 